\title{
2015 年における各研究委員会の活動
}

本報告は，本学会の下記各研究委員会の 2015 年に おける活動の状況について，特にマリンエンジニアリ ング技術の進歩向上に貢献した事項，あるいは，その 基盤として調査検討した事項について各研究委員会委 員長に執筆をお願いし，編集委員会において取りまと めたものです.

\section{機関第一研究委員会}

\section{1. 委員会概要}

機関第一研究委員会は，大手造船会社 6 社，大手船 会社 6 社，官公庁および関連法人の参加で構成されて おり，現在の委員数は 18 名（内，オブザーバ 1 名） である. 本研究委員会の目的は, 主として, 船舶の機 関部の基本計画および運航に関わるテーマを選定して 活動することにある。これまで，特に主機周辺の諸問 題をテーマに活動してきており，近年では，舶用機関 におけるガス焚きエンジンおよびその周辺の動向に関 する調査や, NOx, SOx 3 次規制に関する情報収集と 情報交換, また, JIME ガイドライン化の検討作業等 に対して，精力的に活動している委員会である.

\section{2. 平成 27 年度委員会開催日}

本研究委員会では, 下記の日程で委員会を開催した. 平成 26 年度に引き続いて, 各回において, $\mathrm{NOx}, \mathrm{SOx}$ 3 次規制に関わる各エンジンメーカの対応に関して, エンジンメーカから担当者をお招きし，勉強会のスタ イルで話題提供をして頂き, 質疑応答を行って Q\&A の形式にて資料を作成した他，JIME ガイドライン化 に関する審議を行った。 また，委員同士の情報交換の 場としても，いずれも積極的に利活用される委員会と なった.

第 406 回 平成 27 年 3 月 26 日

第 407 回 平成 27 年 7 月 2 日

東京海洋大学にて

第 408 回 平成 27 年 8 月 20 日

住友重機械 ME にて

第 409 回 平成 27 年 10 月 21 日

川崎汽船にて

三菱重工にて

第 410 回（第 10 回機関第一，第二，第三合同）

平成 27 年 12 月 4 日 三宮研修センターにて
上記のうち，第 410 回委員会は，機関第一，第二， 第三研究委員会の合同委員会として開催した．合同委 員会では，各研究委員会における最近の活動状況につ いて紹介の後, 各委員会の過去に提出した研究報告書 のJIMEガイドライン化への取り組みの進捗状況につ いて意見交換を行った他，今後の合同研究委員会のよ り円滑な開催方法についても意見交換を行った. また， 本合同委員会において，海上保安大学校の西村先生を 講師に迎え,「事故分析一護衛艦あたご/漁船清徳丸衝突 事故」と題して話題提供をして頂いた後，活発な質疑 応答があった。

\section{N0x, SOx 3 次規制に関わるエンジンメーカ各 社および周辺機器メ一カ各社の取り組みについ $\tau$}

平成 27 年度の活動内容は, 平成 26 年度に引き続い て, NOx, SOx 3 次規制に関わるエンジンメーカ各社, および, 周辺機器メーカ各社の取り組みについて, 担 当者をお招きし，勉強会のスタイルで話題提供を頂い た後，活発な質疑応答を行い，その結果を，Q\&Aの 形で記録したものを，支障のない範囲で報告書として とりまとめ,ゆくゆくは会員の皆様にも提供するべく, 活動作業を行っている. 平成 27 年度は, 以下の 7 社 より, 話題提供をして頂いた.

1. バルチラエンジンの NO x 3 次規制への取り組みに ついて

2. 尿素水について

バルチラジャパン 木原氏

三井化学 岩月氏

3. ダイハツ IMO Tier III 対応 SCR 装置

ダイハツディーゼル 花本氏

4. 三井-MAN B\&W 機関 NOx 3 次規制への対応

三井造船 島田氏

5. ヤンマーSCR システムの紹介

ヤンマー 濱岡氏

6. ディーゼルユナイテッドの NOx 3 次規制対応につ いて

$$
\text { ディーゼルユナイテッド 中島氏 }
$$

7. 新潟原動機の NOx 3 次規制対応について

新潟原動機 亀高氏

\section{3. 合同委員会の開催}


今後もこのスタイルを継続し, 一通りのエンジンメ 一力各社の対応の様子について，担当者をお招きし， 話題提供を頂いて勉強会を実施する予定であり, 最終 的には, それらを取りまとめて, 報告書を提出する予 定である. 今後は更に, 周辺機器メーカ各社, 特に, SOx スクラバー関連メーカを予定している.

\section{5. 活性化への取り組み}

ここ数年に亘って，機関第一，第二，第三研究委員 会による合同研究委員会を開催し,相互の交流を深め, 本研究委員会における研究活動に向けての活性化に取 り組んでおり, 平成 27 年度も同様に実施した. 第二 研究委員会が会場の手配を行い, 第一, 第三研究委員 会で交互に話題提供を行う体制が確立し，今後も積極 的に継続していきたいと考えている．また，機会があ れば，第二，第三研究委員会に，少なくとも委員長が 出席して, 情報交換を活発化させ, 親睦を深め, 相互 の活性化に役立つよう, 良いアイデアを出してゆきた いと考えている.

[委員長 地引＼cjkstart達弘］

\section{機関第二研究委員会}

\section{1. 全般}

本研究委員会は 14 名の委員によって構成され，そ の内訳は, 大学・研究機関等 4 名, 船会社 2 名, 造船 所 6 名, 舶用機器メーカ 2 名である. 今年度も, 下記 の様に計 4 回の委員会を開催し, 研究内容の審議, 情 報交換等を行った.

(1) 第 213 回（2015 年 5 月 29 日）

神戸大学 海事科学部 (出席者 8 名)

(2) 第 214 回 (2015 年 9 月 18 日)

神戸大学 海事科学部（出席者 6 名）

(3) 第 215 回（第 10 回機関第一・第二・第三合同

研究委員会 [2015 年 12 月 4 日])

三ノ宮研修センター（出席者 6 名）

(4) 第 216 回（2016 年 2 月 26 日）

神戸大学 海事科学部 (出席者 4 名)

\section{2. 主な調査研究事項と内容}

（1）LNG を燃料とする主機関についての補機類の開発 に関する動向調査

今後，普及が広まると期待されている，LNG を燃 料とする主機関の補機類の現状と技術開発に関する資 料をまとめ, 内容の確認と情報交換を行った.
また，本テーマに関連し，第 85 回（平成 27 年）マ リンエンジニアリング学術講演会シンポジウムの企画 を行い，「LNG を燃料とする主機関の機関室の構成 機器全般について」をテーマとして，10月 27 日に富 山国際会議場においてシンポジウムを開催した。講演 題目と講演者（敬称略）は下記の通りである.

講演 1 「舶用デュアルフューエルエンジン $(1500 \mathrm{~kW}$ 級) の技術紹介」

西村 勝博（ヤンマー株式会社）

講演 $2 「 \mathrm{LNG}$ 燃料船主機関 28AHX-DF の開発」 佐藤 純一 (新潟原動機株式会社)

講演 3 「舶用デュアルフューエル機関の開発」 高山 義隆（ダイハツディーゼル株式会社）

講演 4 「ガス焚き低速ディーゼル機関 ME-GI の 紹介」

田㴊 隆平（三井造船株式会社）

講演 5 「造船所における DFDE 船機関室設計」 前田 剛幸（川崎重工業株式会社）

さらに，上述の講演内容に低速 2 ストローク型ガス エンジンに関する技術紹介（題目「W-X72DF 機関の 紹介」，(株）ディーゼルユナイテッド 小原涼他著） を加え，会誌特集（51 巻 2 号）の企画を行った.

(第 213 回～第 215 回)

(2) 研究報告書のガイドラインへの見直し作業

研究報告書 (No. 203, 商船機関部設計マニュアル[燃 料油系統]）の内容の確認を行い, 現状に合わせて構成 の見直し, 内容の加除及び修正を行った.

(第 213 回〜第 216 回)

（3）その他

「事故分析-護衛艦あたご/漁船清徳丸衝突事故一」に ついて講演が行われ，講演の後，活発な質疑応答が行 われた（第 10 回機関第一・第二・第三合同研究委員 会).

\section{3. 活性化への取り組み}

昨年に続き，具体的な研究調整，協力，及び委員相 互の親睦及び交流を図る場として第一種研究委員会間 によって合同研究委員会を開催し，委員会活動の活性 化に努めた. 本年度は, 第 215 回において, 機関第一・ 第三研究委員会との合同研究委員会を開催し, 解説と 勉強会 (講演テーマ:「事故分析-護衛艦あたご/漁船清 徳丸衝突事故一」）の後, 研究委員会活動のあり方など 
に関して，意見交換を行った。

\section{4. 次年度に向けての目標}

（1）LNG を燃料とする主機関についての補機類の開発 に関する動向調查

昨年度に引き続き, 普及が広まると期待されている, LNG を燃料とする主機関の補機類の現状と技術開発 に関する資料をまとめ, 内容の確認と情報交換を行い, 現状の課題や問題点について検討を行う.

（2）研究報告書のガイドラインへの移行作業

研究報告書 $($ No.203: 商船機関部設計マニュアル[燃 料油系統]) をガイドラインとしてまとめるため, 内容 の確認を行い，現状に合わせて構成の見直し，内容の 加除及び修正を行う.

（3）委員会活動の活性化について

今年度も機関第一・第二・第三合同の研究委員会の 開催により, 研究委員会の横のつながりを強化すると ともに共通寸るテーマを検討, 委員の知見拡大ととも に, 研究委員会相互のさらなる活性化を図る.

[委員長 角 和芳]

\section{機関第三研究委員会}

\section{1. 全般}

機関第三研究委員会は, 日本マリンエンジニアリン グ学会の第一種研究委員会の一つとして, 主として船 舶の機関艤装に関する調査・研究を行っている.

造船所からの委員を中心として，その他大学等から の委員により構成され，基本的には 2 日間にわたる研 究委員会を年 3 回開催, 機関艤装現場における技術上 の問題点等を整理し活発な意見交換を行うとともに, 䑶装工程の管理および効率化に資するガイドラインの 提案などについて検討を重ねている.

平成 27 年度は, 環境規制対応機器搭載にともなう 設計および䑶装上の問題点などを中心に審議を行うと ともに, 機関艤装に関し広く情報交換を行った. また, これまでの研究成果の一部について電子ファイル化及 びマリンエンジニアリングガイドラインフォーマット への移行作業を行った.

なお，学会活動の活性化を目指し毎年実施してきた 機関第一, 第二及び第三研究委員会合同研究委員会を, 平成 27 年度も開催した.

\section{2. 委員会開催状況}

平成 27 年度の委員会開催状況は, 次のとおりであ
る.

第 211 回 平成 27 年 6 月 25 日, 26 日 三菱重工業(株) （長崎）

第 212 回 平成 26 年 10 月 29 日, 30 日

(株)神田造船所 (吳)

第 10 回 機関第一/第二/第三合同研究委員会

平成 27 年 12 月 4 日

三宮研修センター(神戸)

第 213 回 平成 28 年 2 月 25 日, 26 日

三井造船(株)

（玉野）

\section{3. 主な調査研究事項}

(1) ガイドライン関連

ガイドライン「ディーゼル船機関室諸管系統図」,「機 関室配置設計便覧」および「主機潤滑油サンプタンク設 計マニュアル」について，改訂のための見直しを行っ た.

また，報告書「発電機関の艤装」「「主機及び補機の レジンチョックによる据付指針」,「機関部配管艤装要 領」および「予備配管装備基準」について，フォーマ ット変更に備えた電子ファイル化作業を行った.

（2）艤装に関する情報交換関連

主機関からの窒素酸化物排出規制対応機器の搭載, 低硫黄燃料または留出油もしくは LNG 一の燃料油の 転換，バラスト水処理装置の搭載等にかかる機関部艤 装上の問題点，あり方などについて情報交換を行うと ともに，艤装指針の提案に向けて意見交換を行った. 平成 27 年度の主な議題は, 次のとおりである.

(1) バラスト水処理装置の搭載設計および艤装上 の問題点について

(2) EGR の搭載設計および艇装上の問題点につい $\tau$

(3) SCR の搭載設計および艤装上の問題点につい $\tau$

(4) $\mathrm{SO}_{\mathrm{x}}$ 規制対応装置の導入指針について

(5) 機関艤装において最近問題となった事項につ いて

\section{4. 活性化への取り組みとその他の活動}

学会活動活性化の一環として, 平成 27 年 12 月 4 日, 第 10 回機関第一/第二/第三合同研究委員会を三宮研修 センター(神戸)において開催した。この合同委員会で は，衝突事故事故分析にかかる講演のほか，ガイドラ イン作成における各委員会の取り組み状況の報告等, 意見交換を行い委員会間の連携を図った. 


\section{5. 平成 28 年度目標}

「発電機関の艤装」等これまでの報告書について, 現状 に即した改訂を行うことを目的とした見直しを行うと ともに，フォーマットを整理する．また，各造船所間 の情報交換等を活発に行うことにより，艤装に関する 調査研究等を進める. なお, 引き続き合同研究委員会 等を開催し, 各研究委員会及び学会の活性化を図りた い.

[委員長 吉田 肇］

\section{エネルギーシステム研究委員会}

\section{1. まえがき}

環境保全とエネルギー有効利用のため, 原子力船を 含む船舶機関に関するエネルギーシステムの調査研究 及び産業用ボイラ, 船用補助ボイラ水質管理及び廃熱 回収等省エネルギー技術並びに燃料電池関連技術に関 する調査研究を行った.

\section{2. 委員会等開催状況}

平成 27 年度の委員会等開催状況及び内容は, 次の とおりである。

第 1 回委員会 平成 27 年 9 月 28 日 川崎重工業(株) 坂出造船工場にて LNG 船の現地調查実施

第 2 回委員会 平成 27 年 10 月 26 日 富山国際会議 場，「舶用動力・エネルギーシステムの動向」オーガ ナイズセッション企画

第 3 回委員会 平成 28 年 1 月 21 日 九州大学伊都キ ヤンパス, 話題提供 (1) 燃料電池船の実用化の可能 性と課題，(2) 電気化学計測法による燃料電池運転状 態の評価, (見学) 水素システム見学

第 4 回委員会 平成 28 年 1 月 22 日 三菱重工業(株) 長崎造船所にて再熱ボイラの現地調査

\section{3. 主な調査研究事項}

（1）舶用推進機関システムに関する調査

舶用推進機関として,蒸気タービン(主機)の動向調査 を行った. LNG船用URA型主機タービン及び舶用再 熱タービンであるLNG船用MR- II 型主機タービンの 動向について調査を行った. ガスタービン主機の動向 調査を行った.

（2）環境にやさしいエネルギー利用に関する調査

二相閉ループサーモサイフォンを応用した船舶で活
用できる省エネルギーシステムについて研究を行った。 （3）舶用エネルギーシステムにおける省エネルギー技 術に関する調查

廃熱回収タービン及びパワータービンとの組合せの 廃熱回収システムについて動向を調査した，再熱再生 タービンプラント用 LNG 船向けリヒートボイラの動 向調査を行った。発電機の廃熱を利用した省エネ形ボ イラ及び排ガスエコノマイザの動向調査を行った．船 用補助ボイラの水質管理に関する調查を行った. 補助 ボイラとして，コンポジットボイラ，排ガスエコノマ イザ，熱媒ボイラの動向調査を行った．新たに，燃料 電池船の可能性と課題等について調査研究を行った.

\section{4. 年鑑の分担執筆}

下記委員が中心になって調査し，年鑑を分担執筆し た.「蒸気タービン」: 宇藤誠二委員（三菱重工業舶用 機械エンジン),「ボイラ」: 伊丹良治委員 (海技大),「ガ スタービン」: 西上 均委員 (川崎重工業), 「燃料電 池」: 北原辰巳委員 (九州大, 次期委員長)

\section{5. 活性化への取り組み状況}

新しい試みとして第 1 回研究委員会及び第 4 回研究 委員会現地調査において学会学生会員の研究参加を実 施した.

\section{6. 次年度の目標}

船舶に利用できる新たな動力システム，船舶で活用 できるエネルギーシステム及びそれらに関連した熱流 動問題, 燃料電池船の可能性と課題等及び水素エネル ギーシステムについての調査研究を行う.

[委員長＼cjkstart福田＼cjkstart勝哉］

\section{ディーセル機関研究委員会}

\section{1. まえがき}

本研究委員会は，主に舶用ディーゼルエンジンを対 象として,機関およびそれに関連する技術の情報交換, 研修の場として運営し，機関の技術開発や運用面にお ける諸課題について調査研究を行っている。 これまで 行ってきた排気ガス清浄化技術，エンジン燃焼におけ る要素基礎研究課題に加えて，ガス燃料適用に関寸る 諸課題の検討を新たな調查項目として調査研究を開始 している. 


\section{2. 委員会開催状況}

2015 年度の第 51 期には, 合計 3 回の研究委員会を 開催した. そのうち 1 回は, 学術講演会での企画シン ポジウムを兼衩ての開催とした. 各研究委員会の開催 日・場所, 提供された技術講演は下記のとおりである.

第 1 回(通算 253 回)研究委員会 (第 85 回学術講演 会シンポジウム, 委員参加者 12 名)

2015 年 10 月 27 日（富山国際会議場）

・IMO NOx TierIII対応低圧 EGR システム（三菱重 工舶用機械エンジン株式会社)

・IMO NOx Tier III対応 SCR 装置（ダイハツディー ゼル株式会社)

・2 サイクルディーゼル機関の複合低環境負荷システ ム"K-ECOS"（川崎重工業株式会社）

・電子制御式燃料噴射装置を用いたディーゼルエンジ ン (阪神内燃機工業株式会社)

-排ガス規制対応代替燃料利用技術（三井造船株式会 社)

- 低着火性燃料の燃焼・排気に関する実験的解析（国 立研究開発法人海上技術安全研究所）

第 2 回(通算 254 回)研究委員会 (第 85 回学術講演 会でパラレル開催されたシンポジウム内容, 委員参加 者 19名）

2015 年 12 月 8 日（新梅田研修センター）

・舶用デュアルフューエルエンジン（1500kW 級）の 技術紹介（ヤンマー株式会社）

・ガス焚き低速ディーゼル機関 ME-GI の紹介（三井 造船株式会社)

・舶用デュアルフューエル機関の開発（ダイハツディ 一ゼル株式会社)

第 3 回 (通算 255 回) 研究委員会 (エミッション低減 技術とガス燃焼に関する情報交換，委員参加者 22 名）

2016 年 3 月 4 日（新梅田研修センター）

・SOx スクラバーのご紹介（ダイハツディーゼル株式 会社)

・マイクロパイロット着火方式における希薄予混合ガ 不燃焼の着火，排気特性（国立研究開発法人海上技 術安全研究所）

•GI エンジンにおける高圧ガス噴流の空気導入に関す る考察 (九州大学)

\section{3. 調査研究項目}

ディーゼル機関への社会的要請は，ここ十数年はエ ミッション低減が大きな割合を占めている. NOx 排出 低減のために IMO が制定した国際規制は, 2005 年に 全海域対象の 1 次規制が有効となった後, 2011 年の 2 次規制を経て, 2016 年 1 月には 3 次規制 (ECA のみ) が有効になったところである.

それに対応して, 本研究委員会ではディーゼル噴霧
や噴霧燃焼の現象理解とともに，エミッション低減に 向けた技術について調査研究を重祆てきた. 昨年の第 85 回学術講演会では, シンポジウム企画担当に合わせ て，集大成として「排ガス規制対応技術の最新動向」 をテーマに最新の技術について報告した.

また，舶用機関で使用する燃料中硫黄含有量の上限 值規制によって粒子状物質 PM, 硫黄酸化物 SOx の低 減が，エネルギー効率設計指標 EEDI によって二酸化 炭素 $\mathrm{CO}_{2}$ の低減が, 国際的に図られているところであ る. それらへの対応技術は, 引き続き研究委員会の調 查研究対象と寸る.

さらに，次世代燃料の候補である「ガス燃料」につ いて体系的な調査研究に着手した. ガス燃料の燃焼は, ガスの分子組成や構造から, PM 出せず， $\mathrm{CO}_{2}$ の低減も望むことができる. また持続的 なエネルギー源の確保の意味でも，ガスは有用な燃料 である. 既にデュアルフューエル機関として確立され てはいるが，広く普及する技術として確立させるため の諸課題を，運用面も含めて検討していく.

\section{4. おわりに（活性化と今後の展開）}

本学会の研究委員会は, 第 1 種研究委員会と第 2 種 研究委員会があるが，現在その構成について見直しが 検討されている. 本研究委員会が調査研究の項目とし ているものには, 本学会の他の研究委員会と一部重複 するところもある. 今後は, 研究委員会相互に適宜連 携を図るなど，会員・委員が参加しや寸い研究委員会 の運営を心がけたい.

これまでも試行してきた他学会の関連委員会（日本 機械学会関西支部の内燃機関懇話会・燃焼懇話会, 自 動車技術会のディーゼル機関部門委員会）との合同企 画委員会を引き続き行っていきたい. 機関が対象とす るマーケットは異なるが, 現象としては共通するとこ ろが多く, 異なった視点で開発されている技術につい て相互に理解を深めていきたい.

長らく本研究委員会の小委員会として活動を行って きた「メカトロニクス研究小委員会」は第 51 期をも って活動を終了し，小委員会を閉じることとした.

[委員長 段 智久, 副委員長 花本 健一]

\section{推進装置研究委員会}

\section{1. 委員会の概要}

当研究委員会は, 船級協会 3 名, 大学・研究機関・ 有識者 4 名, 船会社 3 名, 造船所 11 名, 機器メーカ 10 名, 以上 31 名の構成により活動し, 軸系やプロペ ラに関わる幾多の調査研究，標準化および資料作成を 通して船舶の推進装置関連技術の向上に努めている. 


\section{2. 委員会開催状況}

2015 年度は下記 4 回の通常委員会および 1 回の合 同委員会を開催し，調査研究項目の審議および情報交 換を行なった.

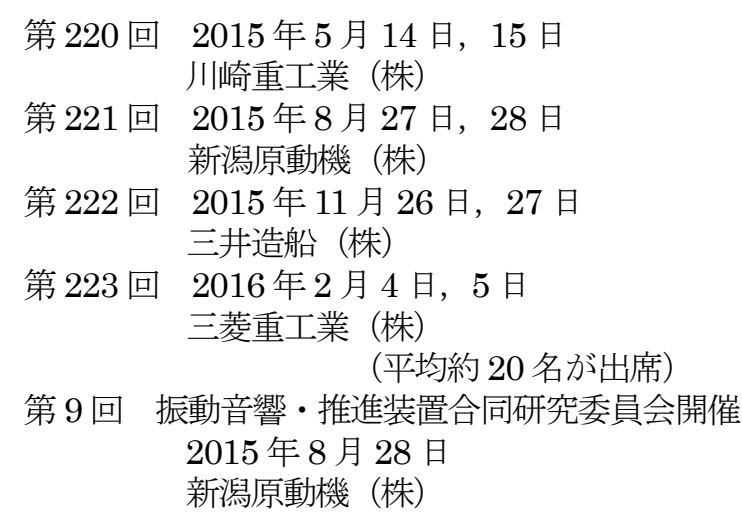

\section{3. 活動実績}

\section{1 調查研究}

（1）軸系関連船級の比較対照表

各船級協会 $(2010$ 年版ベース; NK, ABS, DNV お よび LR）の軸系関連項目の比較対照表を勉強会議題 として作成している.

各船級協会における要求項目の横通しによる差異の 把握をしながら，設計展開する際に考慮すべき注意点 等を備考欄に追記するなどし，今後の若手設計者にと って参考となるような資料作りを進めている.

(2) 電子制御機関採用時における軸系の注意点に関す る調査

電子制御機関採用時における軸系の据付け，アライ メントに関する注意点，ねじり振動低減技術などにつ いて調査し, 2016 年度中に取りまとめの上, 報告する 予定である.

（3）軸系の䑶装工事に関寸る調査

軸系や主機の据付け要領, 据付けに必要な治具等に ついて最新情報を調査し, 2016 年度中に取りまとめの 上，報告する予定である.

（4）軸系アライメントの「計画」と「実測結果のフィ ードバック」に関する調査

軸系アライメントの計算結果と実測結果とを比較し， 両者の関係についての知見を調査している.

\section{2 調査報告書}

軸系関連船級の比較対照表の作成作業を進めており, そのうち下記 3 点を研究報告書としてまとめた. 今後, 若手設計者の参考資料として活用されることを期待す る.

(1) 研究委員会報告 No. 434, 船級規則の比較表「銅 合金鋳物」

(2) 研究委員会報告 No. 435, 船級規則の比較表「第
$1 \mathrm{C}$ 種プロペラ軸に対する追加規定」「プロペラ軸の予 防保全管理」

(3) 研究委員会報告 No. 436, 船級規則の比較表「軸 系の予備品,要具及び装備品」

\section{3 合同研究委員会の開催}

2015 年 8 月 28 日に, 振動音響研究委員会との第 9 回合同研究委員会を新潟原動機（株）にて開催した. 両研究委員会からそれぞれ下記の各 1 件の発表があり, 活発な質疑が行なわれた。

・エンジンと Zペラ推進器が船舶の騒音に及ぼす影響 及びその低減手法の評価に関する研究 (振動音響) ・プロペラフォースと船尾管軸受油膜厚さに関する調 查研究

(推進装置)

\section{4. 今後の活動}

2016 年度も 4 回の委員会を開催し, 各調査研究を 継続していく計画である。 また，諸先輩を講師として お招きし，貴重な経験談等いろいろな講演をしていた だく予定である。昨年度に引き続き振動音響研究委員 会との第 10 回目の合同委員会を開催し，専門的な情 報交換を行ない，研究委員会間の横断的な活性化を図 ることも予定している.

さらに, 今後は推進装置に関わるイベントや展示会 にも参加および見学し，最新技術情報や社会の動向を 把握できるようにする。

最後に, 2016 年度は第 86 回学術講演会においてシ ンポジウムを担当する. 近年の推進装置について最新 情報を分かりやすく提供する予定である.

[委員長 萩原 和也 $]$

\section{振動音響研究委員会}

\section{1. 委員会の概要}

本研究委員会は, 舶用機関, 船舶, 輸送機器, 構造 物および一般機械に関する振動と音響の技術向上に貢 献することを目的に活動を行っている. 委員会は，大 学・研究機関 10 名, 造船・機器メーカ 15 名の計 25 名の委員により構成されている.

\section{2. 委員会開催}

平成 27 年度は 5 回の研究委員会を開催し, 第 3 回 委員会において推進装置研究委員会と合同委員会を開 催し，技術交流を図った. また, CPD 先進コース《振 動・騒音》を担当・実施した。 
第 1 回研究委員会

平成 27 年 4 月 24 日 $\quad$ 日本海事協会

第 2 回研究委員会

平成 27 年 6 月 19 日 (株)郝阪鐵工所

第 3 回研究委員会

平成 27 年 8 月 27 日 新潟原動機(株)

第 4 回研究委員会

平成 27 年 11 月 26-27 日 ダイハツディーゼル(株)

第 5 回研究委員会

平成 28 年 2 月 18 日 ヤンマー(株)宝塚蜻蛉荘

推進装置研究委員会との合同委員会

平成 27 年 8 月 28 日 新潟原動機(株)

\section{3. 委員会活動}

\section{1 水中音および据り振動に関する文献調査}

今後, 規制対象となりうる船舶からの水中音に関し て, 水中音が環境一与える影響や船舶からどの様な水 中音が発生しているか等を把握するため, 最新の文献 (英語論文)の調查を行った．また，近年，環境規制や 機関の低燃費化により様相が大きく変化している㨭り 振動についても, 最新の文献調查の一つとして, 2014 年にオーストリアのザルツブルグで開催された Torsional Vibration Symposium の論文について調査 を行った。これら文献・論文について対象を合計 40 本程度に絞って, 今年度はAbstract を和訳して研究報 告書としてまとめた.

\section{2 CPD 先進コース《振動・騒音》の実施}

12 月 10 日および 11 日に, 福岡県中小企業振興セ ンターにおいて, 以下 7 件の内容で CPD 先進コース 《振動・騒音》を実施した.

1. 大型低速 2 サイクルディーゼル機関の振動・騒音 川崎重工業(株) 西山 徹

2. 中・高速機関の振動・騒音

ヤンマー(株) 冨田 展久

3. 舶用推進軸系の㧖り振動

三井造船(株) 山田 淳司

4. 船体振動

5. 船舶の騒音低隇技術

東海大学 遠山 泰美

東海大学 修理 英幸

6. 軸系ねじり振動に関する船級規則と損傷事例

日本海事協会 宋 玉中

7. 振動・騒音計測法

$$
\text { ブリュエル・ケアー・ジャパン 長友 宏 }
$$

\section{3 活性化への取り組み}

（1）話題提供および情報提供
毎回の委員会において，1 件ずつ話題提供を実施し

て, 質疑応答や活発な議論を行った.

(2) 合同委員会の開催

推進装置研究委員会との合同委員会を開催し，情報 交換と委員の交流を図った。

(3) 見学会の開催

第 2 回研究委員会において赤阪鐵工所, 第 3 回研究 委員会において新潟原動機, 第 4 回研究委員会におい てダイハツディーゼルの工場見学を実施し，種々情報 交換を行った.

\section{4. 今後の委員会活動}

平成 28 年度も 5 回の研究委員会を開催して, 水中 音および㧖り振動に関する論文の調査研究を実施し, 論文本文の和訳要約をまとめていく.

さらに, 推進装置研究委員会との合同研究委員会の開 催, 見学会の開催を継続して実施して, 学会活動の活 性化を図る。

[委員長 山田 淳司 $]$

\section{燃料潤滑研究委員会}

\section{1. 委員会の開催}

本委員会は, 石油会社, エンジンメーカ, 船社, 清 浄機メーカ, 大学, 研究所など幅広い分野に渡る 37 名の委員で構成されており, 2015 年度は, 下記の通り 2 回の委員会を開催した.

（1）第 1 回委員会: 10 月 5 日に東京海洋大学越中島キ ヤンパスにて開催した. 出席者は 20 名で, 下記 1 件 の話題提供, 国際燃焼機関会議舶用潤滑油ワーキング グループ(CIMAC W/G "Marine Lubricants")および 燃料油ワーキンググループ(W/G "Fuels")会議の報告 などを行った。

「環境規制ソリューションーSave Blue一の展望」 乾 貴誌氏（富士電機株式会社）

(2) 第 2 回委員会: 2 月 26 日に東京海洋大学越中島キ ヤンパスで開催した. 出席者は 15 名で, 下記の 2 件 の話題提供と年鑑原稿の執筆担当，国際燃焼機関会議 舶用潤滑油ワーキンググループおよび然料油ワーキン ググループ会議などの報告を行った.

「ガスエンジンの排ガスによる EGR とエマルジョン 燃料が舶用ディーゼ ル機関の排気特性に及ぼす影響」 西尾澄人（海上技術安全研究所）

「インドネシアのバイオ然料のエンジン実験結果」 西尾澄人（海上技術安全研究所）

\section{2. 委員会の活動概要}


NOx, SOx，PM などの削減技術およびバイオ燃料油 に関連した話題提供を中心に委員会を開催した.

国際燃焼機関会議舶用潤滑油ワーキンググループに ついては，日本内燃機関連合会より委託を受け，本委 員会が国内対応委員会となっている. 2015 年度は, 学 会の技術者海外派遣事業の一環として, ピレウス（ギ リシャ)で 4 月に開催されたワーキンググループの第 59 回会議に本委員会から麻野純哉委員(ダイハツディ 一ゼル)が，ハンブルグ (ドイツ) で 9 月に開催された 第 60 回会議に岡田博委員(東京海洋大学)が出席した. 会議の詳細については, 学会誌 50 巻 5 号および 51 巻 1 号の報告記事を参照下さい. また燃料油ワーキング グループについては，日本内燃機関連合会に設置され ている国内対応委員会に協力し，本委員会でも意見の 集約等を行っている.

[委員長 塚本 達郎]

\section{電気電子システム研究委員会}

\section{1. 委員会概要}

当研究委員会の 2015 年度委員数は 23 名で, 大学・ 研究機関・有識者 5 名, 船級協会 4 名, 船会社 1 名, 造船所 5 名, 機器メーカ 8 名で構成されている.

委員会は, 本委員会 4 回及び周囲環境を考慮した電 気設備に関する調査研究の小委員会を下記のように開 催した.

本委員会は，船舶の電気・電子全般に関する新技術 やトピックスなどの情報交換及ひ環境・省エネ・規則 に対する技術動向など幅広く意見交換を行っている. また，マリンンジニアリング入門教育プログラム構築 及び技術者継続教育の支援を行っている.

\section{2. 活動実績}

本研究員会では，下記の日程で委員会を開催した.

本委員会

第1回：4月 10 日 ジャパン マリン ユナイテッド (呉)

第 2 回：7月 10 日 三井造船（築地）

第 3 回 : 10 月 9 日 海上技術安全研究所 (三鷹)

第 4 回： 2 月 12 日 JMU アムテック（相生）

本委員会では，第 1 回委員会において，2015 年度 より開始した周囲環境を考慮した電気設備に関する小 委員会の活動方針について審議を行うと共に，2015 年度活動予定・新規メンバーの加入審議等を実施した. さらに, 2016 年度に新設する小委員会テーマの策定に 際し, 次回開催までに各位の意見を集約するよう課題 とした.
連絡事項としては, 2015 年度研究委員会名簿の確認 を行い，委員の交代及び役職などの確認作業を行った。 また，研究委員会長会議報告および，JIME 正規会員 の登録状況について紹介した.

開催地が大和建造の地である吳市であったことから， 大和ミュージアムを見学し, 戦中から現代に至る造船 技術の発展に感銘を受けた．近年，ベテランから若手 技術者への世代交代が盛んなことから，委員各社の工 場見学だけでなく, 電気電子分野の枠を超えた「見る」

「体感できる」機会を与える事ができた.

また，第 3 回委員会に於いては，海上技術安全研究 所殿にご尽力いただき，電気電子分野の技術者が直接 関与しない水槽試験設備や風水洞設備の施設見学が実 現でき，造船関連技術の知見を深めることができた.

(周囲環境を考慮した電気設備の調査研究 : 主查 三井造船)

第 1 回：4月 24 日 三井造船（築地）

第 2 回：6月 26 日 住友重機械（大崎）

第 3 回：10月 2 日 川崎重工 (神戸)

第 4 回：1月 8 日 株式会社アイピーエス

(三河安城)

2015 年度より開始した本小委員会は, 船舶の振動・ 湿度・温度・EMC 環境等の他, 配置・空調能力・使 用頻度など様々な要因が複雑に関与し，多岐に技術分 野が跨ることが想定されるため, 周囲環境に関わるト ラブル事例の収集とその分析から設計及びメンテナン スによる予防策を提唱寸る方針とした．当初は，トラ ブル事例などが各社・各機関から守秘義務の観点から 出すことができないのではないかと䀣念されたが，船 名や船主名や型番等を伏せる事で委員からの情報開示 をいただくことに見通しがついたため, 単年度で報告 書として完成させることとした.

加えて, 2015 年度より当委員会に新規参画いただい たアイピーエス殿の協力を得ることで，今まで造船技 術者が不得意であった電磁両立性の観点からもトラブ ル予防策が新たに提唱できる知見を得ることが可能と なった．単年度での調査報告ではあるが，内容の濃い 報告書として完成させた.

\section{3. 活性化への取り組み}

当研究委員会での活性化への取り組みとしては，ア イピーエス殿に新規参画いただき, 電磁両立性の専門 的知見を得ることができた．さらに，船舶だけでなく 自動車や家電など, 他業種における EMC の状況を知 ることができ，技術習得の幅を広げることが可能とな った.

また, 継続的な調査研究の実施と技術者継続教育講 習会の支援など学会主催の活動に重点的に取り組んだ. 
また，近年，世代交代に伴い若手の参加者が多いこ とから, 各社の歴史館・工場・研究設備などの見学を 充実させ, 参加者の意識向上に取り組んだ.ささら, 電気学会 - 日本船舶電装協会 - 日本船舶技術研究協会 などの技術的トピックスに関する情報交換を行い，電 気電子の領域を超えた有益な技術情報交流の場として 活動しており, 委員相互の研鑽の場としても充実させ ている.

[委員長 中村 英孝 $]$

\section{材料工学研究委員会}

\section{1. 委員会概要}

当研究委員会は, 舶用機関及び機器並びに海洋機器 に使用される材料の強度, 信頼性, 而久性, 安全性や, 最新の加工技術について調査研究をおこなっている. これらの調査をもとに, 機関・機器が船舶や海洋設備 に搭載され運航される上での問題点，その改善策につ いて検討するとともに，条約・法規及び船級規則によ る規制や，環境負荷低減技術への対応についても情報 収集を行っている。これらの活動や技術者教育への情 報提供などをおこなうことにより，学会及び学会員に 寄与することを目的としている.

\section{2. 委員会開催状況}

研究委員会の開催にあたっては，2 年間にすべての 委員が一度ずつ委員会企画運営を担当するよう 2 名か ら 3 名のグループに分かれて見学先や話題の決定を行 っており, 通常, 年 3 回の研究会実施を目標としてい る. 平成 27 年度については, 以下の通り, 2 回の委員 会を開催した。

(1) 第 1 回研究委員会 $H 27$ 年 11 月 4 日

旭化成ケミカルズ株式会社 川崎製造所にて開催.

\section{【講演】}

・ステンレスの性質と使用上の留意点

・身近に起きた腐食解析事例の紹介

(旭化成エンジニアリング株式会社 日笠久和氏) ステンレス配管等で実際に起こった腐食事例 の紹介とその調查解析手法, 非破壊検查実施時の 注意点や微生物腐食などの特殊な事例について

【施設見学】

・ケミカルプラント内の施設見学及び石油化学製品 の紹介

(2) 第 2 回研究委員会 平成 28 年 3 月 4 日 近江鍛工株式会社 信楽工場にて開催.
【講演】

・電気加工の技術動向

(静岡理工科大学 後藤昭弘教授)

放電加工，電解加工，表面処理など電気加工の

最新技術の紹介とその適用例について

【施設見学】

・リング鍛造や型鍛造を実際に行っているところや， 熱処理に使用寸る炉などを見学

\section{3. 平成 28 年度の計画}

例年通り, 3 回の研究委員会を開催する予定であり, 多くの委員が興味を抱く情報を選定して活性化を図っ ていきたい. 今年度は, 姫路で開催される学術講演会 においてシンポジウムを企画する.

また，平成 19，22，25 年度に続き，JIME 技術者 継続教育 $(\mathrm{CPD})$ 先進コース講習会《材料》の講義開催 を担当する.

[委員長 高橋 千織]

\section{舶用機関の排気エミッション低減に関する 研究委員会}

\section{1. 委員会の概要}

本研究委員会は, エンジンメーカー, 計測器メーカ 一, 研究機関, 大学等に所属する研究者をメンバーと し, IMO の 3 次規制をはじめとする国内外の排ガス規 制を対象とした各種低減方法，自動車等における低減 技術等に関する情報を収集するとともに，これを整理 して所属委員並びに会員に対して現状と今後の方向性 を示すことを目的として設置されたものである.この 目的を達成するために, 必要に応じて, 航海訓練所 (現, 海技教育機構) ・水産大学校の練習船及び実験設備を用 いて実証実験を行っている.

\section{2. 調査研究の内容}

平成 27 年度は次のような活動を実施した.

1. 第 1 回委員会: 平成 27 年 7 月 10 日に東京海洋大 学の越中島キャンパスにおいて開催した. 議事の内容 は次の通りである.

（1）平成 27 年度事業計画について

(2) 平成 27 年度学術講演会における OS（オーガナ イズドセッション）について

(3) IMO 3 次規制対応技術の動向について

(4) その他 
2. 第 2 回委員会: 平成 27 年 10 月 26 日に開催された “第 85 回（平成 27 年度）マリンエンジニアリング学 術講演会”において, オーガナイズドセッション「船舶 起源排気エミッションの低減技術」として講演の募集 を行い，次に示す計 12 件の講演を実施した.

（1）舶用ディーゼルエンジンとガスエンジンを組み合 わせた EGR システムによる排ガス特性の改善（海上 技術安全研究所)

（2）ガスエンジンの排ガスによる EGR とエマルショ ン燃料が舶用ディーゼル機関の排気特性に及ぼす影響 (海上技術安全研究所)

(3) 舶用 2 ストロークディーゼル機関から排出される PM $の$ OC-EC 分析と粒径分布の計測 (東京海洋大学, 海上技術安全研究所）

（4）静電サイクロン方式 DPF と新方式スクラバ装置 による舶用ディーゼル機関の排ガス浄化に関する研究

(東京海洋大学, 古堅 - 牧野技術研究所, JX 日鉱日 石エネルギー，海上技術安全研究所）

（5）ディーゼル噴霧に及ぼすノズル内部構造の影響 (岡山大学, 商船三井, ディーゼルユナイテッド, 栄 和技研)

（6）気体分離膜を用いた筒内酸素濃度分布の導入によ るガスエンジンのメタンスリップ低減一第 1 報 : 過給 システムの実現性およびメタンスリップ低減の可能性 の数值予測（九州大学）

（7）エマルション燃料の NO 低減効果の数值解析によ る検討（九州大学）

（8）水混合燃料による舶用ディーゼル機関の燃費低減 (水産大学校)

（9）水混合 BDF の燃焼特性（水産大学校）

（10）酸素低減膜と水混合燃料による IMO 3 次規制対 応 (水産大学校, 旭化成ケミカルズ)

（11）実船実験による酸素低減膜の性能評価（水産大学

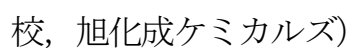

（12）低硫黄燃料の多量水エマルジョンによる NOx, SOx 規制適合技術の可能性（大島造船所，九州大学)

3. 第 3 回委員会: 平成 28 年 3 月 18 日に東京海洋大 学の越中島キャンパスにおいて開催した. 議事の内容 は次の通りである.

（1）平成 27 年度事業報告について

(2) 平成 28 年度事業計画について

(3) IMO 3 次規制対応技術について

(4) EEDI（Energy Efficiency Design Index）等に関 する話題提供

（5）その他
2011 年 7 月に開催された IMO 第 62 回海洋環境保 護委員会（MEPC62）において，「エネルギー効率設 計指標（EEDI）」及び「船舶エネルギー効率管理計画 書 (SEEMP)」を強制化するための MARPOL 条約附 属書VIの改正案が採択され，2013 年 1 月 1 日に発行 した。この条約は，原則として国際航海に従事する 400GT 以上の全ての船舶に適用され, 条約一の適合が 認められた船舶に対しては, 国際エネルギ一効率証書, 通称 IEE（International Energy Efficiency）証書が 発給される. 国際海運における $\mathrm{CO}_{2}$ 排出は全世界の約 $3 \%$ を占め, ドイツ 1 国に相当するが, 国際海運は UNFCC (気象変動枠組条約) 京都議定書における削 減対象外であり, IMO で規制又は削減を追求すること となっている.一般に, $\mathrm{NOx}$ と然費 $\left(\mathrm{CO}_{2}\right.$ 排出量 $)$ は トレードオフの関係にあるとされ，これまでの IMO による NOx 規制対応においても，ある程度の燃費 $\left(\mathrm{CO}_{2}\right.$ 排出量) 悪化を認める方向であったが，今後は 「燃費を改善しつつ NOx 等の大気污染物質を低減す る技術」が求められることになる. 当委員会としても, これを踏まえつつ今後の対応策を検討していくととも に, 今年 10 月に姫路で開催される「平成 28 年度学術 講演会」においてシンポジウムを設置し，広く会員の 皆様に対する情報提供の場を設ける.

[委員長 前田 和幸 $]$

\section{船舶冷凍空調 - 環境調和技術研究委員会}

\section{1. 委員会および講演会等の開催}

平成 27 年度研究委員会は, 以下の日時・場所・出席 者数で 4 回開催した.

○第 8 回研究委員会 平成 27 年 6 月 24 日 東京海洋大学海洋工学部 出席者 13 名

○第 9 回研究委員会 平成 27 年 10 月 25 日 富山市 出席者 7 名

○第 10 回研究委員会 平成 27 年 12 月 4 日 【公開研究委員会】

「冷凍運搬船および風圧力低減型省エネ船の建 造技術」旭洋造船株式会社（下関市）

出席者 33 名 (内委員 7 名)

第 11 回研究委員会 平成 28 年 3 月 15 日 東京海洋大学海洋工学部 出席者 13 名

なお, 委員会での審議・研究交流等の詳細な内容に ついては, 学会ホームページ上に議事録を公開してい るので, そちらを参照 (http://www.jime.jp/j/abouts/ rc/s_ref/s_ref.html) 願いたい. また, 以下の項目につ いて企画提案し, 準備・運営等を行った.

会誌特集の企画 
今期委員会活動の総括として, 特集号「船舶冷凍 空調・省エネ不技術の最新動向」(件数 : 10 件) を 学会誌 (第 50 巻 4 号) に投稿した.

○第 85 回学術講演会でのオーガナイズドセッショ ン (以下 OS)

第 85 回学術講演会（富山）の OS「船舶冷凍空 調・環境調和技術」内で, 基調講演 1 件, 一般講 演 8 件の企画・運営を行った.

$\bigcirc$ 公開研究委員会の開催

第 10 回委員会において, 公開研究委員会を企画 した。「冷凍運搬船および風圧力低減型省エネ船 の建造技術」として旭洋造船株式会社（下関市） にてミニ講演会および見学会を開催した. 公開研 究委員会の参加者は, 33 名 (内委員 7 名) であ り, 内 12 名は学生であった.

公開研究委員会報告

本研究委員会が企画・運営した 2 件の公開研究委 員会に関して, 報告を学会誌（第 50 巻 4 号, 第 51 巻 2 号) に投稿した.

\section{2. 事業報告}

本研究委員会は, 本年度で第四期 (平成 25 年度〜平 成 27 年度) の最終年度となることから,船舶・海洋シ ステムの HCFC 系冷媒から HFC 系・自然冷媒一の転 換にともなう対応技術や低質熱源の有効利用・伝熱促 進技術の情報収集・調査研究・研究交流を主活動とし て行いつつ，第四期のまとめを行った.

研究課題の詳細は，(1）「船舶の冷凍冷蔵・空調用 冷媒の現状と将来展望」として, 船舶・海洋システム の HCFC 系冷媒から低 GWP 系・自然冷媒への転換に ともなう対応技術の情報収集・調查研究・研究交流や, 関連する規則について調查・情報交換. (2)「舶用機器 の省エネ化のための低質熱源の有効利用・伝熱促進技 術および自然エネルギーの利用技術等の調查研究」と して, 船舶機関廃熱の有効利用技術や高性能熱交換器 についての調査研究, 自然エネルギーを活用した省エ ネシステム・先端冷凍空調システムの船舶一の応用と 実現性についての調査などが上げられる。

本年度の研究委員会では, 上記 2 件の研究課題に関 連して, まず第 84 回学術講演会におけるシンポジウ 么「船舶冷凍空調・省エネ不支術の最新動向」の発表内 容と今期委員会活動の総括として，特集号を学会誌第 50 巻 4 号に投稿した. 次に, 第 85 回学術講演会（富 山）において基調講演 1 件，一般講演 8 件からなる OS「船舶冷凍空調・環境調和技術」の企画・運営を行 った。 また, 研究課題(1)，(2)に関連し，冷凍運搬船の 建造技術および船舶における省エネ化技術に関して特 殊な技術を有する旭洋造船株式会社（下関市）におい て公開研究委員会を開催した. 本公開研究委員会は学 会活動の活性化という観点から，学生参加を積極的に
促し参加者 33 名中 12 名は学生であった. 当日は, 造 船所側の 2 名の講師によるミニ講演会と造船所構内の 見学会を実施し, 特に䘬装最終段階での風圧力低減型 コンテナ船の見学に関しては非常に好評であった。 な お，平成 26 年度および 27 年度に本研究委員会が企 画・運営した 2 件の公開研究委員会（「船舶の中低温 排熱からの動力回収・発電技術」，「冷凍運搬船および 風圧力低減型省工不船の建造技術」)については, 学会 誌第 50 巻 4 号, 第 51 巻 2 号に報告を掲載しているの で，そちらも参照頂きたい.

\section{3. 来期の事業計画および委員会活性化}

来期の事業計画としては, 年 $3 \sim 4$ 回の委員会開催 を予定している。研究テーマとしては，「船舶の冷凍 冷蔵・空調用冷媒の現状と将来展望」および「舶用機 器の省エネ化のための低質熱源の有効利用・伝熱促進 技術および自然エネルギーの利用技術等の調査研究」 に引き続き取り組むことを考えている．また，第 86 回学術講演会においては, 船舶冷凍空調・環境調和技 術に関する OSにおいて研究発表を予定している.

本研究委員会では, これまでと同様に学会誌や学会 ホームページ上で, 委員会活動報告や学術講演会での 委員会内容について会員に広く開示を行い，加えて一 般会員・学生向けの企画事業についても, 公開研究委 員会や見学会という形で，積極的に提案していく予定 である.

[委員長 井上 順広 $]$

\section{海洋浮遊ゴミの処理システムに関する 調查研究委員会}

\section{1. 調査研究委員会の概要}

本調査研究委員会は設置当初から, 対馬海流によ つて運ばれてくる外国由来の海洋浮遊ゴミの海岸 漂着により，海岸環境破壊や生活居住環境に甚大な 影響を受けている長崎県対馬市を調査研究のモデ ル地としてきた. それ以来, 地元の NPO 森里海再 生協議会の協力のもと, 持続性のある海洋浮遊ゴミの 工学的な処理システムによる循環型社会の構築に向け て, 調査研究を行っている.

\section{2. 委員会活動}

今年度の委員会活動は 2 つ分科会方式で行なった。 海洋を漂流している状態の浮遊ゴミを洋上で効果的に 捕捉する方法を検討するグループと，海岸に漂着した 浮遊ゴミの大部分を占める外国由来の発泡スチロール 
を工学的に処理する方法を検討するグループである. 委員長と幹事が両方の分科会に出席することで双方の 調整を図りながら, 海洋浮遊ゴミの処理システムの確 立に向けた調查研究活動を行った。

また, 前年度から参加した長崎県・対馬市が進める 対馬環境プロジェクトにおいては,「漂流・漂着ゴミの 資源化処理」を検討し，「対馬環境エネルギーコンソー シアム会議」等で検討結果を発表した.

\section{1 漂流ゴミ関係}

平成 27 年 4 月 14 日一長崎総合科学大学

待ち受け式浮遊フェンスの構造, 衰引方法の検討,

及び水槽実験方法内容の決定.

平成 27 年 4 月 27 日一西日本二チモウ

待ち受け式浮遊フェンスの捕捉部構造, 収納方法の 討議.

平成 27 年 9 月 14 日一水産大学校

待ち受け式浮遊フェンスの実験結果と構造の検討報 告，収納方法の紹介及び討議.

\section{2 漂着ゴミ関係（発泡スチロール）}

平成 27 年 4 月 27 日一大島商船高専

発泡スチロールの減容化装置の構造検討と減容化実 験方法の決定

平成 27 年 8 月 11 日一大島商船高専

再生可能エネルギーによる減容化作業電力の供給方 法の検討と減容化における必要電力量に関する討議

平成 27 年 8 月 27 日一大阪府立大学

自然再生可能エネルギー（風力発電）による発電量 モニタリング方法と実験方法の検討

平成 27 年 9 月 16 日一大島商船高専

対馬における環境教育用資料（対馬市教育委員会 ESD 活動）の作成内容の検討

平成 27 年 10 月 7 日一大島商船高専練習船大島丸: 神 戸港停泊）

減容化実験報告と減容化装置の設計緒元・留意事項 の検討

\section{3 イベント}

平成 27 年 8 月 $22 \sim 24$ 日一対馬市上県町佐護

第3 回日韓海岸清掃フェスタ in 対馬 (主催: 対馬市, ふるさと清掃運動会, 美しい対馬の梅ネットワーク) において，大島商船高専で開発した発泡スチロール の減容化実験装置や器材をイベント会場に持ち込み, 漂着発泡スチロールの減容化作業を実演した（図 1 参照). イベント参加者から大きな注目を集め, 当日 の様子は長崎新聞等で大きく報道された. 更に, 対 馬市教育委員会から小中学校における環境実践教育
（ESD 活動）として減容化実験を採り入れる方針が 示された。
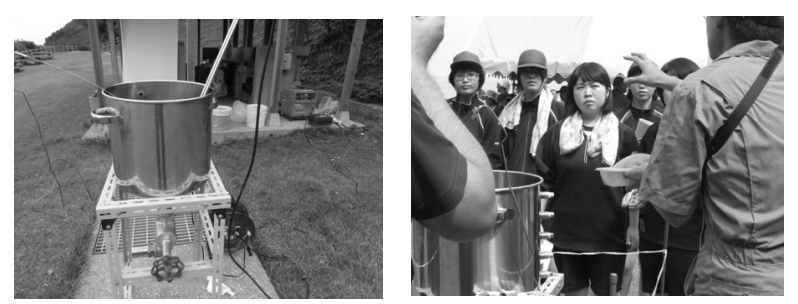

図 1 イベント会場での減容化実演デモ

平成 27 年 10 月 $23 \sim 25$ 日一五島市福江町

一般社団法人 JEAN による第 13 回海ごみサミット 2015 長崎・五島会議に，当委員会のメンバーである 対馬市の NPO 森里海再生協議会の三原叶也理事長 が出席し，ポスター展示等を行った。

\section{4 対馬環境エネルギーコンソーシアム関係} 平成 27 年 6 月 1 日一福岡

第 8 回対馬環境エネルギーコンソーシアム会議 : 平 成 27 年度の方針とバイオマス発電に関する事例報 告

平成 27 年 10 月 19 日一福岡

第 9 回対馬環境エネルギーコンソーシアム会議 : 漂 流ゴミの洋上捕捉方法として, Mr.Boyann Slat（才 ランダ）が提唱する係留固定フェンス方式が森原会 長より紹介された。

平成 28 年 3 月 23 日一福岡

第 10 回対馬環境エネルギーコンソーシアム会議： 漂流・漂着ゴミの資源化処理に関し，発泡スチロール の減容化処理とマテリアルリサイクルが，地元に与え る雇用の促進と経済波及効果等について，委員長が発 表した.

\section{3. 調査研究事項}

海洋浮遊ゴミによる海洋・海岸環境污染や破壊に対 して，漂流ゴミの効果的な待ち受け式無係留浮遊つェ ンスによる捕捉，及び漂着ゴミの大部分を占める発泡 スチロールの回収後の輸送の合理化と工学的な資源化 処理システムについて検討を行った，その結果を以下 に記す。

（1）浮遊フェンスの断面構造は，浮遊ゴミの 60～70\% が軽量の発泡スチロールであることに留意し，捕捉滞 留時の飛越拡散を防止するために水面上の高さを $60 \mathrm{~cm}$ とし，ネットの高さを水中支柱式のフロートで 維持する構造に決定した. 
（2）浮遊フェンスの収納方法は, 敷設海域で速やかに 展張する作業性よりも, 小型船舶に搭載する移動性を 重視し，折り重祆て收納する方法に決定した.

（3）発泡スチロールの減容化後の容積は, 熱溶媒の温 度が $160^{\circ} \mathrm{C}$ 以上であればほぼ一定值 $(1$ /発泡倍率) で, 減容化中の温度の低下は微小であることが実験的に把 握出来た.

（4）減容化は試料と熱溶媒の接触面積を重視すべきで, 貝類や海藻類の付着物は減容化中に離脱して底部に沈 殿する，但し，軽量な細片は減容化物に付着する傾向 がある. また, 大型発泡体の分断作業は, 切断時にビ 一ズ状となった発泡体による健康影響が想定されるこ とから回避すべきである.

（5）減容化に必要な電力を賄う風力および太陽光によ る再生可能エネルギーによる発電方式は, 発電空白時 間対策としてハイブリッドシステムとする，充電装置 は軽量化ではリチウム, コストでは鉛であり, 海岸立 地環境を考慮すると鉛式装置が有力である.

（6）回収後の発泡スチロールの減容化による輸送費の 減額効果を, 対馬市が実施している漂着ゴミの海岸清 掃事業で回収した発泡スチロール 2,500 トン袋につい て試算した。 なお，輸送先は長崎県佐世保市の焼却処 理場とした. その結果, 輸送に必要な大型トラックの 所要台数が $1 / 20$ となることがわかった

（7）熱溶媒（廃天ぷら油）で減容化した発泡スチロー ルについては脱塩効果が認められたことから, 漁業用 のブイや養殖用のフロートの原料として再利用（マテ リアルリサイクル）する方向が見出され, 燃料化（サ 一マルリサイクル）に続く新たな資源化の可能性が誕 生した.

\section{4. 次年度に向けて}

地産地消型の漂流・漂着ゴミの処理・資源化による 地域経済振興と雇用の創出（ミニエコ生活経済圈の創 成）を目指していく中で, 次年度は以下の調査研究を 進めていく.

（1）減容化ポリスチロールのマテリアルリサイクル 廃食用油を熱溶媒とした漂着発泡スチロールの減 容化は脱塩効果と付着物の脱離性に優れていること から, 漁業用のブイやフロートの生産用の原料とし て再使用するマテリアルリサイクルの可能性が見出 され，付加価值の高い資源化処理システムの誕生を 見込める状況となった. そこで，この処理システム の構築と地域の経済に与える影響について検討する. （2）再生可能エネルギーによる巡回移動式減容化処理 離島や僻地の電力インフラが未整備な地域での減容 化処理には独立電源が必要である. これらの地域に適
した風力・太陽光のハイブリッドによる発電システム の構築を検討する.

（3）重要海岸線前の漂流ゴミの捕捉・回収の運用シス テムの検証

地域の観光資源となっている風光明媚な海岸線や漁 獲活動の重要な拠点となっている海岸線への浮遊ゴミ の漂着被害を未然に防ぐために，海象・気象情報から 漂流物の漂着地を予測し, その海岸線前に浮遊つェン スを敷設する方法と漂着防止効果について検討する. 一机上展開演習等

（4）減容化ポリスチロールによる省エネ・省力化の検 証

漂着発泡スチロールの減容化による回収後の輸送費 用の削減効果，およひ輸送作業の省エネ・省力効果を 検証するとともに減容化装置の改良を図り，地域に定 着し持続する処理システムの確立を検討する.

(5) 漂流ゴミの漂着地点の予測と運用システムの構築

現在九州大学等が観測している潮流の流況性データ 等から, 漂流物の漂着地点を予測するシミュレーショ ンソフトと, 浮遊フェンスの展張や浮遊ゴミを回収す るハードを組み合わせて運用を図るシステムの構築を 検討寸る. また，マイクロプラスチックの漂流問題に 対しても調查研究を行う.

[委員長 三原 伊文]

\section{海洋環境研究委員会}

\section{1. 委員会の概要}

マリンエンジニアリングが関わる海洋環境に関して, 幅広い専門分野の学際ネットワークを構築し, 委員相 互の意見交換の場とすることを目的とする．従来から 取り組んできた有機スズおよび非有機スズ防污物質の 環境影響評価や，新しい防污システムを主題として継 続しながら，新たに防污システムの価值，海洋環境の 污染と修復にも取り組む.

\section{2. 委員会活動}

研究委員会を下の通り 3 回開催した. 内第 2 回は, 第 4 回ワークショップとして開催した. 参加者は 30 ６0 人で, 熱心な討論が以下開催地で行われた.

第 1 回（2015 年 6 月 1 日 海上技術安全研究所 東 京都三鷹市)

(1) 内湾堆積物の化学物質污染

横浜国立大学 中村 由行 
（2) 閉鎖性海域での底泥と低層に蓄積する硫化水素 国立環境研究所 牧 秀明

(3) 光触媒による海中細菌の処理機構の解明 産業技術総合研究所 根岸 信彰

・施設見学（操船リスクシミュレーター，深海水 槽)

第 2 回（第 4 回ワークショップ「船底塗料と海洋環境 に関寸る最新の話題」, 2015 年 9 月 16 日〜 17 日 函 館国際水産・海洋総合研究センター 北海道函館市)

【招待講演】

(1) 震災復興がもたらした人為的攪乱-外来種ナンオ ウフジッボの東北への侵入と分布拡大の懸念北里大学 加戸 隆介

(2) 船底防污塗料および国際動向について 中国塗料株式会社 千葉 知義

【一般講演】

(1) キプリス幼生着生率の青色 LED 放射照度依存 性

神戸大学 三村 治夫

(2) フジツボの付着前行動と付着基質選択性との関 係について

旭川医科大学 室崎 喬之

(3) アカフジツボ新規幼生セメント候補タンパク質 Mr-lcp60k の発見

秋田県立大学 遠藤 健斗

(4) ChemcatcherTM パッシブサンプリングによる 水中污染物資モニタリング スリーエムジャパン株式会社 山口 裕顕

(5) 瀬戸内海表層海水中における溶存態銅の調查 $(2015$ 年度調査) 神戸大学 阿部 徹

（6) 神奈川県沿岸海域に棲息するアマモ Zostera marina における船底防污塗料の蓄積特性 東京農工大学 大地 まどか

(7) 海洋付着生物に対するクレハ PGA(ポリグリコ 一ル酸)の効果に関寸る基礎検討 セシルリサーチ 山下 桂司

（8) バイオミメティックスの超撥水性の船底塗料の 効果 ナノテクバンク 武木田 義祐

(9) Natural products as antifouling strategy- the case of compounds from organisms of the Red Sea

$$
\text { 北海道大学 ジュリー ペチーボア }
$$

(10)スジアオノリを用いた防污塗料の新しい性能評 価手法の検討

日本 NUS 松村 知明

(11) タテジマフジツボを用いた防污塗料の新しい性 能評価手法の検討
日本 NUS 勝山 一郎

- 企業展示 (セシルリサーチ, ジーエルサイエン 又株式会社)

- 施設見学（函館水産・海洋総合研究センター, 函館どつく)

第 3 回 (2016 年 2 月 29 日 ツイン $21 ・ M I D$ タワー)

(1) イオン液体の性質を利用した表面濡孔性制御技 術の開発

岡山大学 小野 努

(2) 藻類や植物のクロロフィル遅延発光計測技術と その応用

浜松ホトニクス 勝又 政和

(3) 二枚貝を用いた重金属影響および生物センサー に関する研究

九州大学 姜 益俊

\section{3. 次年度に向けて}

引き続き, 年 3 回の研究委員会の開催を（できるか ぎり公開委員会として）計画している.また，JIME 会 員に興味のある, (1)実験施設や設備の見学会を取り入 れること, (2)他研究委員会との合同開催をする予定で ある。

[委員長 小島 隆志 $]$ 